\title{
KÖSZÖNTJÜK AZ OLVASÓT!
}

Úi tudományos folyóirat születéséhez s remélt felcseperedéséhez invitáljuk olvasóinkat. Lapunk rendhagyó a tudományos folyóiratok sorában: nem egyetlen szaktudomány eredményeit teszi közzé, hanem egy problémát: tér és társadalom viszonyát vizsgálja a különböző szaktudományok szemszögéböl, sajátos megközelitésben.

A lap programjának meghatározásában az a kiindulópontunk, hogy a társadalmi folyamatok megértéséhez, pontos feltárásához és elörejelzéséhez éppen olyan szükségünk van térbeliségük, földrajzi dimenziójuk vizsgálatára, mint idő́beliségük, történetiségük elemzésére, vagy e folyamatok általánositott modellekbe rendezésére. Nemcsak arról van szó, hogy számos társadalmi folyamatnak - gazdasági növekedés, urbanizáció, társadalmi kiegyenlítödés stb. - leirható földrajzi eloszlása van, hanem arról is, hogy e folyamatok alkalmazkodni kénytelenek a természeti és társadalmi térhez, módosulnak a földrajzi környezet hatására. Ezért a társadalmi folyamatok konkrét megjelenési formái csak a földrajzi környezet ismeretében értelmezhetök.

"Tér" alatt nem a filozófia vagy a fizika térfogalmát értjük, hanem az emberlakta teret, vagyis a földfelszín ama részét, amelyet a társadalom használ, amelybe betelepült. E térnek vannak természeti tulajdonságai, amelyek az ember lamely élölényként a természet része) teljes tevékenységére - társadalmi, kulturális tevékenységére is - hatnak. Folyóiratunk figyelmének egyik központjában a társadalom és a természeti környezet kapcsolata, kölcsönhatása áll.

Az ember persze egyidejüleg él természeti és társadalmi környezetben. Az ember ökológiai elterjedése során fokozatosan szerzett tapasztalatokat - s közvetített generációról generációra - a természeti környezetröl, amelytöl kezdetben erösen függött, s amelyben eléggé bizonytalanul, fenyegetettve élt. Az elsó társadalmi szervezet, a család, az egyén biztonságának érdekében alakult ki. A társadalmi környezet a tér fokozódó használata közben kibontakozó ember-tér és ember-ember kapcsolatok öszszessége.

Az ember-tér kapcsolatok - folyóiratunk fö tárgya - sokfélék. Például az ember tevékenysége során mozog a tér különbözö pontjai között, s így eltérő mozgásterek alakulnak ki. Ilyenek a napi munkábajárás vagy bevásárlás terei. Az egyéni mozgáspályák összeadódnak, $s$ az embercsoportok által követett pályák a tér kitüntetett pontjaiban csomósodnak. Ezek a pontok vonzzák magukhoz a mozgásokat, vonzásközpont szerepúek, kiemelkednek a térnek csak lakóhelyül szolgáló pontjai közül. A vonzásközpontok a városokban sürüsödnek; a városokhoz igy a vonzott terek soka- 
sága kapcsolódik (a bennük élö népességgel). A falu föleg lakóhely-szerepũ; vonzást gyakorló intézményeinek (iskola, üzlet) hatása a lakóhelyen belül marad. A városi vonzáskörzetekben összegezödö falu-város kapcsolatok feltárása is fontos vizsgálati területünk lesz.

Amikor az ember térben mozog, különbözö rendeltetésû, szerepû tér-részletek között mozog. A különbözö terek között a mozgáskapcsolatokat nemcsak a személyek, de termékek, energia, információk cseréje is közvetíti.

A társadalomföldrajz az emberi tevékenységet hét alapfunkcióra osztja. Ezek: a lakás, a munkavégzés; szolgáltatás - ellátás; képzés - kultúra; üdülés - pihenés; közlekedés - kommunikáció és a közösségi élet. E funkciók gyakorlásához meghatározott tér-részletek, földrajzi sajátosságok, társadalmi szervezetek, (épített) berendezések tartoznak.

A társadalmi alapfunkciókat hordozó terek fekvése, jellege, kiépitettsége a társadalmi igények kielégitésének nagyon fontos eleme. Az ember nemcsak dolgozni, vásárolni, kulturálódni akar, hanem ezen igényeit egy számára elfogadható méretü térségen belül kívánja kielégíteni. Ha erre nincs módja lakóhelyéról kiindulva, akkor vagy lakóhelyét változtatja meg, vagy saját kívánatos életmódját kell megcsonkítania, saját társadalmi rétegszintje vagy egvéni igényszintje alatt kell élnie. A települések közötti és a településeken belüli társadalmi feszültségek jórészt a fentiekböl fakadnak.

A társadalmi igények és a kiszolgáló terek eltérése bizonyos mértékig állandóan fennáll. A településeknek a népesség mobilabb eleme, mint a funkcionális terek. Hazánkban a terek spontán, a létezó helyi társadalmi igényekhez alakítása korlátozott, hiszen ezek zömmel tervezett terek, a településtervezés hozza létre, szabályozza, fejleszti öket. A tervezés pedig átlagokkal és normákkal dolgozik, a helyben - községben, városnegyedben stb. - létezó társadalmi igényeket nem is ismeri. Ezért tervek és igények találkozása mindig tökéletlen lesz; hiány és pazarlás egyaránt elöfordulhat.

Az igények és'a funkcionális terek jobb egyezését segítheti elő a spontán térszerveződés bövülése, a helyi társadalom nagyobb lehetösége saját használt terének megszervezéséhez. Jelenleg ugyanis a különbözö funkciójú terek múködtetésében túlzott szerepet kap a funkciót gyakorló szervezet belsó szakmai szempontja, hatalmi érdeke, s ehhez a társadalmi csoportoknak - gyakran saját érdekeik csonkításával - alkalmazkodniuk kell, nincs mód érdekeik megfelelö érvényesítésére.

Sajátos térkapcsolatokat hoz létre a második gazdaság, ameíy minden fejlett országban jelentôs. A második gazdaság "kibújik" az állam által tervezett terekból, megbontja a hagyományos gazdasági tér-struktúrát, új, spontán, részben rejtett, de funkcionáló térszervezeteket hoz létre. Igv hát a fejlett országok területén különbözö térszervezö erő́k müködnek: nagy térségekben az állam és a külső (nemzetközi) erók, kis térségekben a helyi társadalom szervezeteinek, a mikroökonómiai szervezeteknek erői - eltérő mechanizmusokban, szabályozottság és spontaneitás eltéró arányaiban. Mindez a tér és társadalom viszonyát bonyolulttá teszi - e viszonyrendszer feltárása, sokoldalú megismertetése, társadalmi fejlödésünk szempontjából történö értékelése lesz folyóiratunk fö feladata.

ENYEDI GYÖRGY 